NATIONAL LABORATORY

\title{
Reactor Pressure Vessel Task of Light Water Reactor Sustainability Program: Level 2 Milestone (M2LW-12OR0402015) - Results of Examinations of Surveillance Specimens from Commercial Reactors
}

\section{September 2012}

Prepared by

R. K. Nanstad, M. K. Miller, and W. D. Lewis Materials Science and Technology Division Oak Ridge National Laboratory

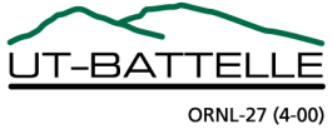


This report was prepared as an account of work sponsored by an agency of the United States Government. Neither the United States Government nor any agency thereof, nor any of their employees, makes any warranty, express or implied, or assumes any legal liability or responsibility for the accuracy, completeness, or usefulness of any information, apparatus, product, or process disclosed, or represents that its use would not infringe privately owned rights. Reference herein to any specific commercial product, process, or service by trade name, trademark, manufacturer, or otherwise, does not necessarily constitute or imply its endorsement, recommendation, or favoring by the United States Government or any agency thereof. The views and opinions of authors expressed herein do not necessarily state or reflect those of the United States Government or any agency thereof. 
This page intentionally left blank 
ORNL/TM-2012/447

Light Water Reactor Sustainability

\title{
Reactor Pressure Vessel Task of Light Water Reactor Sustainability Program: \\ Level 2 Milestone (M2LW-12OR0402015) - Results of Examinations of Surveillance Specimens from Commercial Reactors
}

\author{
R.K. Nanstad, M. K. Miller, and W. D. Lewis \\ Materials Science and Technology Division \\ Oak Ridge National Laboratory \\ Date Published: September 2012 \\ Prepared under the direction of the \\ U.S. Department of Energy \\ Office of Nuclear Energy \\ Light Water Reactor Sustainability \\ Materials Aging and Degradation Pathway
}

Prepared by

OAK RIDGE NATIONAL LABORATORY

Oak Ridge, Tennessee 37831-6283

managed by

UT-BATTELLE, LLC

for the

U.S. DEPARTMENT OF ENERGY

under contract DE-AC05-00OR22725 
This page intentionally left blank 


\section{CONTENTS}

\section{Page}

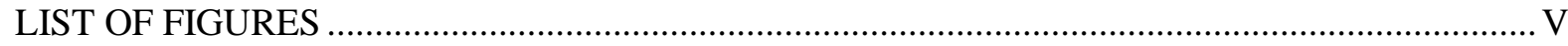

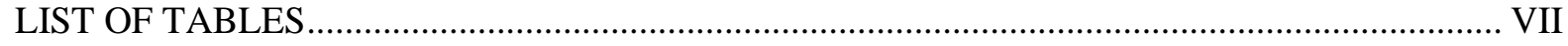

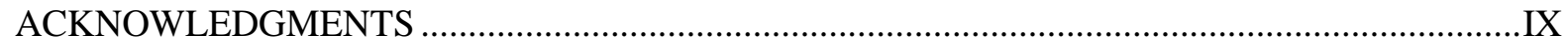

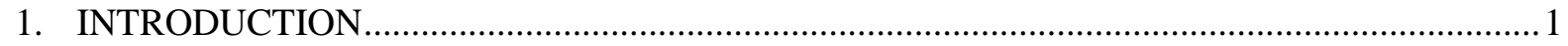

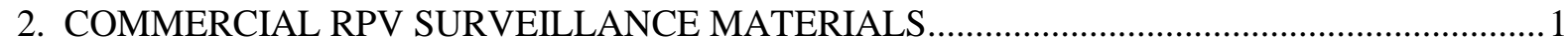

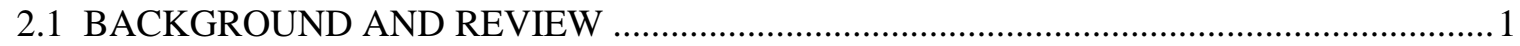

2.2. EXAMINATION OF MATERIALS FROM THE RINGHALS REACTORS......................2

2.3. EXAMINATION OF MATERIALS FROM THE R. E. GINNA REACTOR ......................5

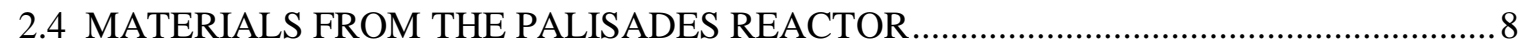

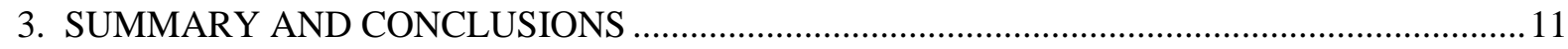

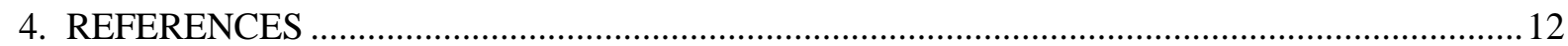

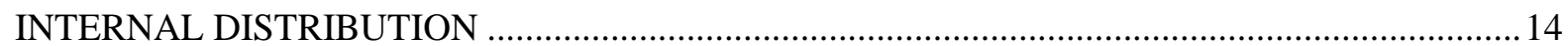

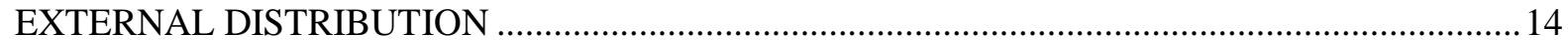


This page intentionally left blank 


\section{LIST OF FIGURES}

Figure

Figure 2.1 Curve fits to Charpy V-notch impact data for Ringhals Unit 3 weld metal surveillance

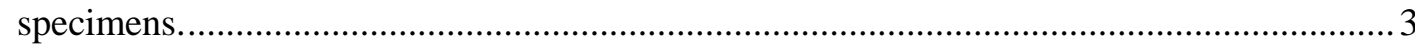

Figure 2.2 Atom probe tomography of a NiMnSi precipitate in an irradiated surveillance specimen from the Ringhals Unit 3 reactor. .5 
This page intentionally left blank 


\section{LIST OF TABLES}

Table

Page

Table 2.1. Irradiation conditions for Ringhals surveillance specimens. ............................................ 4

Table 2.2 Compositions of the two Ringhals RPV materials used in this study. Fe is the balance........ 4

Table 2.3 R. E. Ginna Nuclear Reactor Surveillance Specimens ...................................................... 6

Table 2.4 Transition temperature shifts for R. E. Ginna materials. .................................................... 7

Table 2.5 Results of hot cell microhardness measurements of R. E. Ginna surveillance specimens ...... 7

Table 2.6 Copper and nickel measurements for the PNP reactor vessel surveillance plate.................... 8

Table 2.7 Copper and nickel measurements for the PNP reactor vessel surveillance weld and HAZ

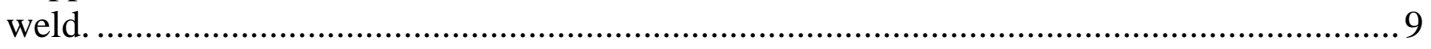

Table 2.8 Contents of Palisades Nuclear Plant Capsule A-60 .......................................................... 10 
This page intentionally left blank 


\section{ACKNOWLEDGMENTS}

This research was sponsored by the U.S. Department of Energy, Office of Nuclear Energy, for the Light Water Reactor Sustainability Research and Development effort. The authors extend heir appreciation to Dr. Jeremy Busby for programmatic support. For the atom probe tomography results, the authors acknowledge that Research supported in part by ORNL's Shared Research Equipment (ShaRE) User Facility, which is sponsored by the Office of Basic Energy Sciences, U.S. Department of Energy 
This page intentionally left blank 


\section{INTRODUCTION}

The reactor pressure vessel (RPV) in a light-water reactor (LWR) represents the first line of defense against a release of radiation in case of an accident. Thus, regulations that govern the operation of commercial nuclear power plants require conservative margins of fracture toughness, both during normal operation and under accident scenarios. In the unirradiated condition, the RPV has sufficient fracture toughness such that failure is implausible under any postulated condition, including pressurized thermal shock (PTS) in pressurized water reactors (PWR). In the irradiated condition, however, the fracture toughness of the RPV may be severely degraded, with the degree of toughness loss dependent on the radiation sensitivity of the materials. As stated in previous progress reports, the available embrittlement predictive models, e.g. [1], and our present understanding of radiation damage are not fully quantitative, and do not treat all potentially significant variables and issues, particularly considering extension of operation to $80 \mathrm{y}$.

The major issues regarding irradiation effects are discussed in $[2,3]$ and have also been discussed in previous progress and milestone reports. As noted previously, of the many significant issues discussed, the issue considered to have the most impact on the current regulatory process is that associated with effects of neutron irradiation on RPV steels at high fluence, for long irradiation times, and as affected by neutron flux. It is clear that embrittlement of RPV steels is a critical issue that may limit LWR plant life extension. The primary objective of the LWRSP RPV task is to develop robust predictions of transition temperature shifts (TTS) at high fluence $(\phi t)$ to at least $10^{20} \mathrm{n} / \mathrm{cm}^{2}(>1 \mathrm{MeV})$ pertinent to plant operation of some pressurized water reactors (PWR) for 80 full power years. New and existing databases will be combined to support developing physically based models of TTS for high fluence-low flux $\left(\phi<10^{11} \mathrm{n} / \mathrm{cm}^{2}\right.$-s) conditions, beyond the existing surveillance database, to neutron fluences of at least $1 \times 10^{20} \mathrm{n} / \mathrm{cm}^{2}(>1 \mathrm{MeV})$. All references to neutron flux and fluence in this report are for fast neutrons $(>1 \mathrm{MeV})$.

The RPV task of the LWRS Program is working with various organizations to obtain archival surveillance materials from commercial nuclear power plants to allow for comparisons of the irradiation-induced microstructural features from reactor surveillance materials with those from similar materials irradiated under high flux conditions in test reactors. This report provides the status for the Level 2 Milestone (M2LW-12OR0402015), "Complete Examination of Reactor Surveillance Specimens." This milestone is associated with procurement of materials from three commercial

power reactors, R. E. Ginna, Ringhals, and Palisades, for performance of microstructural examinations.

\section{COMMERCIAL RPV SURVEILLANCE MATERIALS}

\subsection{BACKGROUND AND REVIEW}

In [4], materials for five different projects were described and discussed; (1) Materials for the ATR-2 experiment, (2) Materials from the Zion reactor, (3) Materials from the Ringhals reactors, (4) Materials from the R. E. Ginna reactor, and (5) Materials from the Palisades reactor.

The LWRS Program, in cooperation with EPRI, the NRC, and Westinghouse, is engaged in discussions with Zion Solutions, Inc., owner of the Zion Nuclear Plant, Units 1 and 2. These two reactors have been shut down since 1998, having operated for only about 15 effective full power years. A number of specific recommendations have been made by the RPV task of the LWRS Program relative to information provided by Zion Solutions, Inc. These recommendations are to obtain specific identified tested and untested surveillance specimens from both Zion 1 and Zion 2 for examination, and to obtain a large section of Zion 2 for direct examination of the RPV. 
A detailed description of the materials from the Ringhals Reactors was presented in [5] and will be summarized in this report. Dr. Pal Efsing of Vattenfall AB in Sweden has provided small samples of surveillance materials removed from tested Charpy impact specimens. All the surveillance specimens are from low-copper high-nickel weld metals in Ringhals Units 3 and 4, both pressurized water reactors. These specimens have been used to prepare samples for atom probe tomography and small-angle neutron scattering to characterize the microstructure relative to irradiation-induced precipitates and other defects, and some early results are discussed in Section 2.2.

Materials from the R. E. Ginna reactor were described in [6], and additional updated information is discussed in this report in Section 2.3. Materials from the Palisades Reactor were also described in [6] and a brief review and update of information is presented in Section 2.4.

\subsection{EXAMINATION OF MATERIALS FROM THE RINGHALS REACTORS}

A significant issue associated with such predictive capability is that of RPV materials containing relatively high nickel content and the Ringhals reactors discussed in this report contain weld metals with very high nickel contents. There are some U.S. RPVs with relatively high nickel content; e.g., the Palisades Nuclear Plant RPV contains a weld with about 1.3 wt\% nickel (see section 2.4). The primary objective of the U.S. Department of Energy's Light-Water Reactor Sustainability Program (LWRSP) RPV task is to develop robust predictions of transition temperature shifts (TTS) at high fluence $(\Phi)$ to at least $10^{20} \mathrm{n} / \mathrm{cm}^{2}$ pertinent to plant operation of some pressurized water reactors (PWR) for 80 full power years. New and existing databases will be combined to support developing physically based models of TTS for high fluence-low flux $\left(\phi<10^{11} / \mathrm{n} / \mathrm{cm}^{2}\right.$-s $)$ conditions, beyond the existing surveillance database, to neutron fluences of at least $1 \times 10^{20} \mathrm{n} / \mathrm{cm}^{2}$.

The strong synergistic interactions between copper, nickel and manganese are understood at low to intermediate fluence. However, the interactions at higher fluence, in both low and higher copper steels, needs to be established. Similarly the basic role of phosphorous is established. However, potential interactions with copper and phosphorous effects at high fluence have not been quantified. Similarly, Si-Ni and Si-Mn interactions also result in silicon enrichment in CRPs. Ref. [3] discusses this issue in some detail pointing out that, even in the absence of copper, thermodynamickinetic models predicted the formation of $\mathrm{Mn}-\mathrm{Ni}$ phases, although at low nucleation rates compared to that for CRPs, the effect being that relatively high incubation fluences are required for their formation.[7-11] For that reason, these features have been coined "late-blooming phases" that may have potential to cause severe embrittlement, even in the absence of significant copper. The existence of LBPs has been experimentally confirmed, with a $\mathrm{Mn}-\mathrm{Ni}$ precipitate in a copper-free, $1.6 \mathrm{Ni}-1.6 \mathrm{Mn}$ wt.\% model alloy shown in [12]. Similar observations have been reported by other researchers around the world and, as seen later in this section, also in the Ringhals surveillance welds.

\section{Background on Ringhals RPV Materials}

The following information is taken from Efsing, et. al. [13]. The Ringhals Units 3 and 4 reactors are pressurized water reactors (PWR) designed and supplied by Westinghouse Electric Company, with commercial operation in 1981 and 1983, respectively. The RPVs for both reactors were fabricated by the Uddcomb Company with ring forgings of SA 508 class 2 material made by Klöckner Werke. Surveillance blocks for both units were also supplied by Uddcomb using the same weld wire heat, welding procedures, and base metals used for the RPVs. The primary interest in these weld metals is because they are very high in nickel content, with 1.58 and $1.66 \mathrm{wt} \%$ for Unit 3 and Unit 4, respectively. For reference, the highest nickel content in the U.S. Nuclear Regulatory Commission Regulatory Guide 1.99, Rev. 2 is $1.20 \mathrm{wt} \%$ [14]. As stated by Efsing, et. al. [13], the 
nickel content in Unit 4 is the highest reported nickel content for any Westinghouse PWR. This high nickel content is, as mentioned previously, the primary reason for interest in examination of the irradiated microstructure of the Ringhals welds.

As expected for such high nickel welds, both weld metals have exhibited very high irradiation-induced Charpy 41-J transition temperature shifts $\left(\Delta \mathrm{TT}_{41}\right)$ in surveillance testing. Figure 1, taken from [13], show results of surveillance tests from four capsules of Unit R3, with similar results for Unit R4 shown in [13]. Ref. [13] also provides the following detailed information:

1. For Unit R3, $\Delta \mathrm{TT}_{41}$ of $192^{\circ} \mathrm{C}\left(345^{\circ} \mathrm{F}\right)$ at $5.0 \times 10^{19} \mathrm{n} / \mathrm{cm}^{2}(>1 \mathrm{MeV})$

2. For Unit R4, $\Delta \mathrm{TT}_{41}$ of $162^{\circ} \mathrm{C}\left(292^{\circ} \mathrm{F}\right)$ at $6.0 \times 10^{19} \mathrm{n} / \mathrm{cm}^{2}(>1 \mathrm{MeV})$

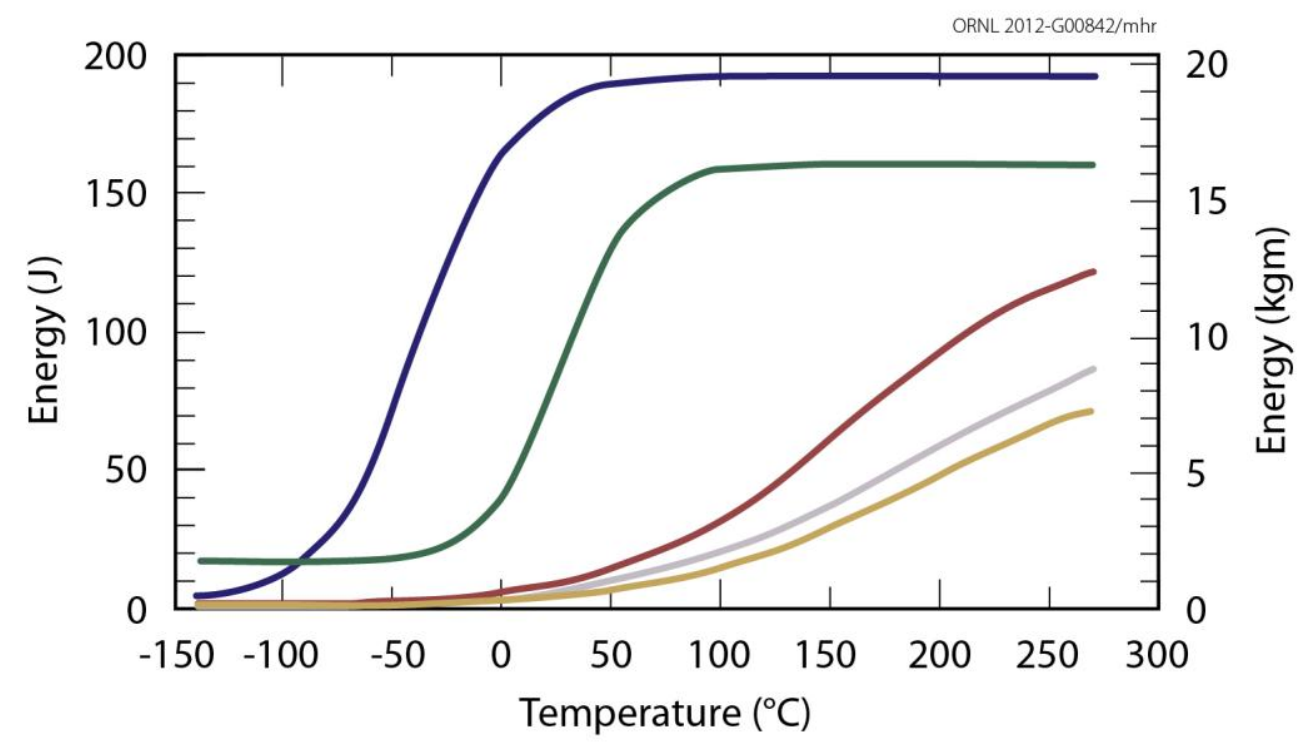

— RA96 — RA84 - RA00U - RA00X — Unirradiated

Figure 2.1 Curve fits to Charpy V-notch impact data for Ringhals Unit 3 weld metal surveillance specimens.

Thus, the radiation sensitivity of both weld metals is extremely high in spite of their low copper contents. Vattenfall AB in Sweden provided ORNL with small samples of surveillance materials removed from tested Charpy impact specimens from Ringhals Units R3 and R4. Tables 2.1 and 2.2 from Vattenfall $\mathrm{AB}$ provide the irradiation conditions and chemical composition for the specimens, respectively.

As shown in Table 2.2, the nickel contents are about $1.6 \mathrm{wt} \%$ with copper contents of 0.08 $\mathrm{wt} \%$ or less. The samples provided by Vattenfall $\mathrm{AB}$ are slices from Charpy impact specimens and are about $10 \times 10 \times 0.4 \mathrm{~mm}$ thick. As stated earlier, these materials are of high interest to the LWRS Program because they have low copper and high nickel contents, have been irradiated to relatively high neutron fluences, and exhibit very significant radiation sensitivity as indicated by the very high Charpy $\Delta \mathrm{TT}_{41}$ values. 
Table 2.1. Irradiation conditions for Ringhals surveillance specimens.

\begin{tabular}{|c|c|c|c|c|c|c|c|}
\hline Specimen & Reactor & Capsule & Material & Temp, ${ }^{\circ} \mathrm{C}$ & Fluence & EFPY & Calculated Flux \\
\hline E6, 3A & R3 & U & Weld & 284 & $6.39 \mathrm{E}+19$ & 13.8 & $1.47 \mathrm{E}+11$ \\
E46,3A & R3 & W & Weld & 284 & $4.34 \mathrm{E}+19$ & 10.4 & $1.32 \mathrm{E}+11$ \\
N11, 3A & R4 & U & Weld & 284 & $6.03 \mathrm{E}+19$ & 12.8 & $1.49 \mathrm{E}+11$ \\
N27, 3B & R4 & V & Weld & 284 & $3.30 \mathrm{E}+19$ & 6.3 & $1.66 \mathrm{E}+11$ \\
\hline
\end{tabular}

Table 2.2 Compositions of the two Ringhals RPV materials used in this study. Fe is the balance.

\begin{tabular}{|l|l|l|l|l|l|l|l|l|l|l|l|l|}
\hline Material & $\mathrm{C}$ & $\mathrm{Si}$ & $\mathrm{Mn}$ & $\mathrm{P}$ & $\mathrm{S}$ & $\mathrm{Cr}$ & $\mathrm{Mo}$ & $\mathrm{Ni}$ & $\mathrm{Cu}$ & $\mathrm{Al}$ & $\mathrm{Co}$ & $\mathrm{V}$ \\
\hline E wt\% & 0.052 & 0.21 & 1.46 & 0.009 & 0.006 & 0.07 & 0.54 & 1.58 & 0.08 & 0.027 & 0.015 & 0.002 \\
\hline N wt\% & 0.068 & 0.14 & 1.35 & 0.0015 & 0.004 & 0.04 & 0.50 & 1.66 & 0.05 & 0.024 & 0.010 & 0 \\
\hline
\end{tabular}

$\underline{\text { Atom Probe Tomography (APT) Experimental Procedures }}$

Atom probe tomography needle-shaped specimens for this study were prepared by standard electropolishing methods [15] with the use of small blanks cut from bulk materials. The electropolishing solutions were $2 \%$ perchloric acid in 2-butoxyethanol. The APT specimens were electropolished at room temperature at $15 \mathrm{~V} \mathrm{DC}$. Atom probe tomography characterization of these surveillance specimens were performed in a Cameca Instruments LEAP® 4000 X HR local electrode atom probe. This instrument features a reflectron lens in the mass spectrometer to improve mass resolving power. The APT analyses were performed in voltage mode with a specimen temperature of $50 \mathrm{~K}$, a pulse repetition rate of $200 \mathrm{kHz}$, an ion collection rate of between 0.5 and 1 ions per pulse, and a pulse fraction of 0.2 .

\section{Atom Probe Tomography Results}

As shown in Figure 2.2, APT measurements of a surveillance specimen from the Unit 3 weld have revealed relatively large irradiation-induced precipitates containing nickel, manganese, and silicon, with phosphorus evident in some of the precipitates. This particular specimen had been irradiated at $284^{\circ} \mathrm{C}$, at a flux of $1.32 \times 10^{11} \mathrm{n} / \mathrm{cm}^{2}$ to a fluence of $4.34 \times 10^{19} \mathrm{n} / \mathrm{cm}^{2}$. Perhaps not surprisingly, the precipitate elemental concentrations are dominated by nickel and manganese atoms, with only a relatively few number of copper atoms contained within the precipitates. Additional APT experiments are underway with specimens from Unit 3 irradiated to a higher fluence of $6.39 \times 10^{19}$ $\mathrm{n} / \mathrm{cm}^{2}$ and the specimens from Unit 4 irradiated to both fluences. 


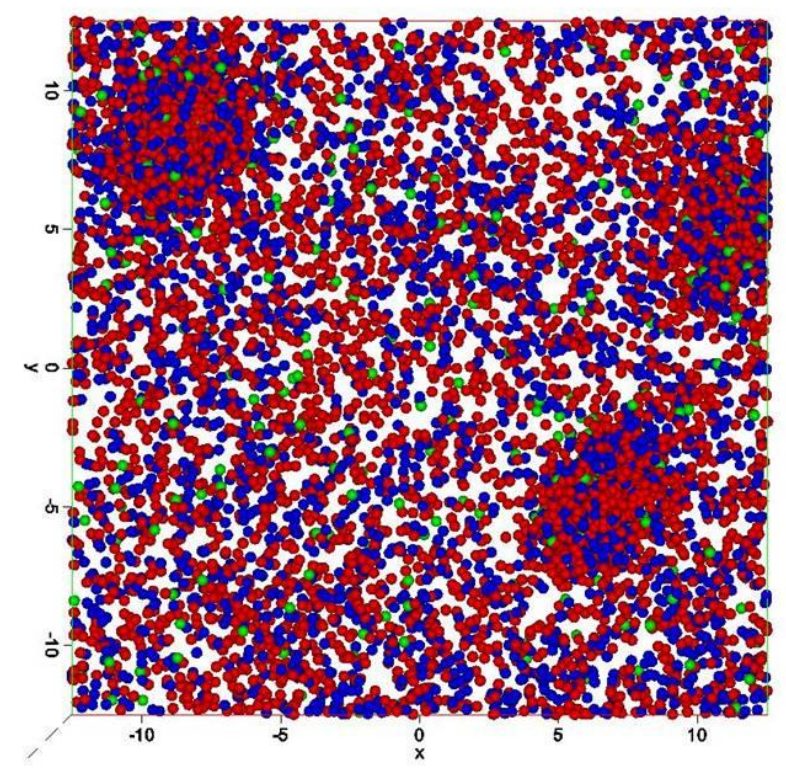

Figure 2.2 Atom probe tomography of a NiMnSi precipitate in an irradiated surveillance specimen from the Ringhals Unit 3 reactor.

\subsection{EXAMINATION OF MATERIALS FROM THE R. E. GINNA REACTOR}

The Nuclear Plant Life Extension Demonstration (NPLED) Project is a partnership between the Department of Energy (DOE), the Electric Power Research Institute (EPRI) and Constellation Energy, owner of the R. E. Ginna Nuclear Plant (also referred to as Ginna). The NPLED will investigate the technical issues and demonstrate analysis methods to achieve nuclear plant life extension to 80 years. Many issues have been identified that are of mutual interest within the partnership, and the methods to investigate the issues will be determined through the DOE LWRS Program and the EPRI Long Term Operation (LTO) Project. Constellation Energy's Ginna and Nine Mile Point nuclear power stations will both be used as the pilot plant sites due to their age ( $>40 \mathrm{y})$ and representation of the PWR and BWR technologies. For the RPV task, materials from the Ginna PWR RPV are of the highest interest due to their higher irradiation fluence and demonstrated irradiationinduced embrittlement from the RPV surveillance program.

The Ginna reactor is a Westinghouse 2-loop PWR that began commercial operation in July 1970 and produces about 580 MWe. The Ginna RPV was fabricated with forgings of A508 class 2 steel and welded with Linde 80 weld metals; these materials were included in the surveillance program. Westinghouse retrieved previously tested surveillance specimens of one forging, one of the welds, and heat-affected-zones form their storage facility. The following information regarding the materials and surveillance test results has been taken from [16]. The weld material from the Ginna surveillance program comes from the circumferential weld joining intermediate shell forging (Heat $125 \mathrm{~S} 255$ ) and lower shell forging (Heat 125P666). The weld is heat number 61782 (this is the weld wire heat no.) and, with the flux lot 8350 , is a Linde 80 weld designated SA-847. The HAZ specimens come from the heat affected zone between the circumferential weld and lower shell forging (Heat 125P666). The weld metal chemical composition includes $0.23 \% \mathrm{Cu}, 0.53 \% \mathrm{Ni}$, and $1.31 \% \mathrm{Mn}$, while the forging chemical composition includes $0.05 \% \mathrm{Cu}, 0.69 \% \mathrm{Ni}$, and $0.67 \% \mathrm{Mn}$ (all $\mathrm{wt} \%$ ). Five capsules have been removed and tested over the course of reactor operation at neutron fluences ranging from $0.58 \times 10^{19}$ to $5.8 \times 10^{19} \mathrm{n} / \mathrm{cm}^{2}$. The specimens provided to ORNL were 
irradiated to $1.69,3.64$, and $5.80 \times 10^{19} \mathrm{n} / \mathrm{cm}^{2}$; for those three fluences, $\Delta \mathrm{TT}_{41}$ values for the weld specimens were 147 to $217^{\circ} \mathrm{F}$ ( 82 to $121^{\circ} \mathrm{C}$ ) and those for the forging were 34 to $91^{\circ} \mathrm{F}\left(19\right.$ to $51^{\circ} \mathrm{C}$ ). Forging specimens were tested in the LT orientation, while those of the weld were tested in the TL orientation. The reactor coolant temperature (assumed to be the irradiation temperature for the surveillance specimens) is given as 545 to $552^{\circ} \mathrm{F}\left(285\right.$ to $\left.289^{\circ} \mathrm{C}\right)$. The latest removal, Capsule $\mathrm{N}$, was performed after 30.5 effective full power years of plant operation.

Table 2.3 shows the surveillance specimens received from Westinghouse. All received specimens are tested Charpy impact specimens from the indicated surveillance capsules. For the HAZ specimens, one Charpy specimen half should be weld metal with the other half forging. The table also shows the total neutron fluence and flux, as well as displacements per atom (dpa) and dpa rate, and the irradiation-induced transition temperature shift, $\operatorname{TTS}\left(\Delta \mathrm{TT}_{41}\right)[16]$.

Table 2.3 R. E. Ginna Nuclear Reactor Surveillance Specimens

\begin{tabular}{|c|c|c|c|c|c|c|}
\hline ID & Type & $\begin{array}{c}\text { Surv. } \\
\text { Capsule }\end{array}$ & Material* & $\begin{array}{c}\text { Fluence, } \\
\text { n/cm² } \\
\text { (dpa) }\end{array}$ & $\begin{array}{l}\text { Flux, } \\
\text { n/cm } \\
(\text { dpa/s) }\end{array}$ & $\begin{array}{l}\Delta \text { TTTS } \\
{ }^{\circ} \mathbf{F}\left({ }^{\circ} \mathrm{C}\right)\end{array}$ \\
\hline $\begin{array}{l}\mathrm{H}-45,46, \\
48,50,54\end{array}$ & $\begin{array}{l}2 \text { CVN } \\
\text { halves } \\
\text { each }\end{array}$ & $\mathrm{N}$ & HAZ & $\begin{array}{c}5.8 \mathrm{E}+19 \\
(0.104)\end{array}$ & $\begin{array}{c}5.92 \mathrm{E}+10 \\
(1.06 \mathrm{E}-10)\end{array}$ & $\begin{array}{l}107.7 \\
(59.8)\end{array}$ \\
\hline $\begin{array}{c}\mathrm{H} 33,35, \\
37,39,40\end{array}$ & $\begin{array}{l}2 \mathrm{CVN} \\
\text { halves } \\
\text { each, } \\
\text { marked } \\
\text { A or B }\end{array}$ & $S$ & HAZ & $\begin{array}{c}3.64 \mathrm{E}+19 \\
(0.064)\end{array}$ & $\begin{array}{c}6.62 \mathrm{E}+10 \\
(1.16 \mathrm{E}-10)\end{array}$ & $\begin{array}{c}38.9 \\
(21.6)\end{array}$ \\
\hline $\begin{array}{c}\mathrm{P} 22,25, \\
26,28,29\end{array}$ & $\begin{array}{l}2 \text { CVN } \\
\text { halves } \\
\text { each }\end{array}$ & $\mathrm{T}$ & Forging & $\begin{array}{c}1.69 \mathrm{E}+19 \\
(0.029)\end{array}$ & $\begin{array}{c}8.12 \mathrm{E}+10 \\
(1.40 \mathrm{E}-10)\end{array}$ & $\begin{array}{c}33.6 \\
(18.7) \\
\end{array}$ \\
\hline $\begin{array}{l}\mathrm{W} 22,23, \\
27,28,30\end{array}$ & $\begin{array}{l}2 \mathrm{CVN} \\
\text { halves } \\
\text { each }\end{array}$ & $T$ & Weld & $\begin{array}{c}1.69 \mathrm{E}+19 \\
(0.029)\end{array}$ & $\begin{array}{c}8.12 \mathrm{E}+10 \\
(1.40 \mathrm{E}-10)\end{array}$ & $\begin{array}{l}149.7 \\
(83.2)\end{array}$ \\
\hline \multicolumn{7}{|c|}{$\begin{array}{l}\text { * NOTE: Forging (lower shell) is A508 class } 2 \text { (Heat 125P666); weld is } \\
\text { SA-837 (weld wire heat } 61782 \text { with Linde } 80 \text { flux lot } 8350 \text { ), HAZ (Heat- } \\
\text { affected-zone) specimens are the Forging } 125 \text { P666 to Weld } 61782 \text {. }\end{array}$} \\
\hline
\end{tabular}

In addition to the information in Table 2.3, reference [16] provides the $\Delta \mathrm{TT}_{41}$ results for the forging, weld, and HAZ at each of the three fluences in Table 2.3. Those results are summarized in Table 2.4. As expected based on the higher copper content of the weld relative to the forging, the weld exhibits significantly greater irradiation-induced shifts vs neutron fluence.

Selected Charpy specimens from each group in Table 2.3 were tested for microhardness in the hot cell as a first step to identify the materials in the HAZ specimens, i.e., to identify which broken Charpy half is weld and which half is forging. Seven measurements were performed on each specimen in the region about $6 \mathrm{~mm}$ from the specimen fracture surface. Table 2.5 shows the average microhardness for each specimen. Based on tensile information in [15], the weld is stronger than the 
Table 2.4 Transition temperature shifts for R. E. Ginna materials.

\begin{tabular}{|c|c|c|}
\hline Material & Fluence, $\mathbf{~ n / \mathbf { c m } ^ { 2 }}$ & $\Delta \mathbf{T T S},{ }^{\circ} \mathbf{F}\left({ }^{\circ} \mathbf{C}\right)$ \\
\hline Forging, Heat 125P666 & $1.69 \times 10^{19}$ & $33.6(18.7)$ \\
\hline “ “ & $3.64 \times 10^{19}$ & $45.8(25.4)$ \\
\hline “ & $5.80 \times 10^{19}$ & $91.1(50.6)$ \\
\hline $\begin{array}{c}\text { Weld, SA-847 (Wire } \\
\text { 61782) }\end{array}$ & $1.69 \times 10^{19}$ & $149.7(83.2)$ \\
\hline “ “ & $3.64 \times 10^{19}$ & $212.2(117.9)$ \\
\hline “ “ & $5.80 \times 10^{19}$ & $216.9(120.5)$ \\
\hline $\begin{array}{c}\text { Heat-Affected-zone } \\
\text { (HAZ) }\end{array}$ & $1.69 \times 10^{19}$ & $41.0(22.8)$ \\
\hline “ “ & $3.64 \times 10^{19}$ & $38.9(21.6)$ \\
\hline “ “ & $5.80 \times 10^{19}$ & $107.7(59.8)$ \\
\hline
\end{tabular}

base metal, and at $1.7 \times 10^{19} \mathrm{n} / \mathrm{cm}^{2}$ the weld specimen is 43 points harder than the forging specimen. Thus, the microhardness measurements for the weld and forging specimens in Table 2.5 are indicative of the strength difference at $1.7 \times 10^{19} \mathrm{n} / \mathrm{cm}^{2}$. For the HAZ specimen $\mathrm{H} 39$ at $3.6 \times 10^{19} \mathrm{n} / \mathrm{cm}^{2}$, both H39-A and H39-B exhibit the same hardness; in this case, the weld should be even harder than at lower fluence. Moreover, at $5.8 \times 10^{19} \mathrm{n} / \mathrm{cm}^{2}, \mathrm{H} 48$-B is only 20 points harder than H48-A. Thus, based on these initial microhardness results, identification of the HAZ specimens as either weld metal or forging cannot be confidently discerned.

Table 2.5 Results of hot cell microhardness measurements of R. E. Ginna surveillance specimens

\begin{tabular}{|c|c|c|c|}
\hline Specimen ID & $\begin{array}{c}\text { Mentified } \\
\text { Material }\end{array}$ & Avg. $\mu \mathrm{H}$ & Fluence \\
\hline P26-Forging & Forging & 223.5 & $1.7 \mathrm{E}+19$ \\
\hline W30-Weld & Weld & 266.4 & $1.7 \mathrm{E}+19$ \\
\hline HAZ - H39-A & $? ?$ & 238.8 & $3.6 \mathrm{E}+19$ \\
\hline HAZ - H39-B & $? ?$ & 237.8 & $3.6 \mathrm{E}+19$ \\
\hline HAZ - H48-A & Forging ?? & 258.1 & $5.8 \mathrm{E}+19$ \\
\hline HAZ - H48-B & Weld ?? & 277.4 & $5.8 \mathrm{E}+19$ \\
\hline
\end{tabular}

The specimens have been sent to our Low Activated Materials Development and Analysis (LAMDA) laboratory and will be evaluated further by additional microhardness tests, chemical etching and chemical composition differences with a portable probe. Once the HAZ specimen materials are unambiguously identified, the specimens will be sectioned to enable fabrication of samples for microstructural examination using atom probe tomography and small-angle neutron scattering. The current available window for SANS beam time in the High-Flux Isotope Reactor (HFIR) is October, 2012. 


\subsection{MATERIALS FROM THE PALISADES REACTOR}

The Palisades Nuclear Plant (PNP) included in its surveillance program a surveillance capsule, designated A-60, containing Charpy impact and tensile specimens of plate (A302 grade B modified, Heat D-3803-1), a surveillance weld and an HAZ weld (both RACO 3 weld wire heat 3277 with Ni200 nickel addition), and a standard reference (correlation monitor) material (HSST Plate 01). Tables 2.6 and 2.7 from PNP provide previous elemental measurements for the materials. ${ }^{1}$ As shown in Table 2.6, the plate has an average copper content of $0.23 \mathrm{wt} \%$ and an average nickel content of $0.51 \mathrm{wt} \%$. Table 2.7 shows that the surveillance weld has an average nickel content of $1.36 \mathrm{wt} \%$ and copper content of about $0.25 \mathrm{wt} \%$, while the HAZ weld has an average nickel content of $1.10 \mathrm{wt} \%$ and copper content of $0.25 \mathrm{wt} \%$. These particular welds were fabricated with a cold-wire feed process to enhance the nickel contents, but which also results in a very large scatter in the nickel contents of both welds. This scatter in nickel content will require specific measurements of each specimen fabricated for microstructural examination.

Table 2.6 Copper and nickel measurements for the PNP reactor vessel surveillance plate.

\begin{tabular}{|c|c|c|}
\hline \multicolumn{3}{|c|}{ PALISADES REACTOR VESSEL SURVEILLANCE PLATE CHEMISTRY } \\
\hline Material & Copper (\%) & Nicke1 (\%) \\
\hline D-3803-1 & 0.22 & 0.49 \\
& 0.25 & 0.48 \\
& 0.24 & 0.53 \\
& 0.24 & 0.53 \\
& 0.215 & 0.52 \\
& 0.215 & 0.523 \\
& 0.215 & 0.496 \\
& & 0.495 \\
\hline \hline Best Estimate & 0.23 & 0.51 \\
\hline
\end{tabular}

The contents of the capsule are provided in Table 2.8. The A-60 capsule was irradiated to a fluence of $1.8 \times 10^{20} \mathrm{n} / \mathrm{cm}^{2}$. The capsule was removed from its surveillance position in June 1995 and has been resident in the spent fuel pool since that time. The intent of this task is to retrieve the capsule, test the tensile and Charpy impact specimens, and examine some of them microstructurally with atom probe tomography and small-angle neutron scattering to assess the irradiation-induced features of this rather unique material condition (very high fluence). The surveillance weld is also of special interest because of its very high nickel content and potential for development of NiMnSi late blooming phases, even in the presence of high copper content.

Discussions were held in FY 2011 with the responsible persons at the PNP who had indicated their willingness to provide the capsule for evaluation. Discussions have also been held staff members of Westinghouse regarding retrieval of the capsule from PNP with one of their new shipping casks that can handle a full length surveillance capsule assembly. The preliminary plan is for Westinghouse to retrieve the capsule and ship it to the Westinghouse hot cell facility, disassemble the capsule to retrieve the specimens, and ship the specimens to ORNL for evaluation. A cost estimate was obtained from Westinghouse for their part of the project. During discussions between Westinghouse and PNP,

1 Information regarding the materials in the PNP A-60 capsule provided in a Letter from John R. Kneeland, Jr. to Randy K. Nanstad, 22 May, 1995. 
the PNP staff stated that ongoing operations at the plant would not allow for retrieval of the capsule until sometime in 2012. Current negotiations with new PNP staff have indicated a feasible cost for the PNP part of the project and the current target date for retrieval of the capsule from the spent fuel pool is February 2013.

Table 2.7 Copper and nickel measurements for the PNP reactor vessel surveillance weld and HAZ weld.

\begin{tabular}{|c|c|c|c|c|}
\hline \multirow[t]{2}{*}{ Weld } & \multicolumn{2}{|c|}{ Copper (\%) } & \multicolumn{2}{|c|}{ Nickel (\%) } \\
\hline & Content & Mean & Content & Mean \\
\hline $\begin{array}{c}\text { Palisades } \\
\text { surveillance } \\
\text { weld }\end{array}$ & $\begin{array}{l}0.26 \\
0.22 \\
0.25 \\
0.30 \\
0.239 \\
0.231 \\
0.233\end{array}$ & 0.25 & $\begin{array}{c}0.63 \\
1.27 \\
1.60 \\
1.38 \\
1.617 \\
1.502 \\
1.494 \\
\end{array}$ & 1.36 \\
\hline $\begin{array}{c}\text { Palisades } \\
\text { HAZ } \\
\text { weld }\end{array}$ & $\begin{array}{l}0.25 \\
0.20 \\
0.26 \\
0.25 \\
0.26 \\
0.27 \\
0.26 \\
0.23 \\
0.27 \\
0.23 \\
0.22 \\
0.22 \\
0.28 \\
0.22 \\
0.27 \\
0.28 \\
0.27 \\
0.23 \\
0.27 \\
0.26 \\
0.21 \\
0.22 \\
0.27 \\
0.23 \\
\end{array}$ & 0.25 & $\begin{array}{l}0.43 \\
1.28 \\
1.22 \\
1.09 \\
1.25 \\
0.98 \\
1.27 \\
1.09 \\
0.90 \\
1.18 \\
1.28 \\
1.27 \\
1.02 \\
1.10 \\
1.22 \\
0.94 \\
1.18 \\
0.89 \\
0.92 \\
1.15 \\
1.29 \\
1.31 \\
1.02 \\
1.12 \\
\end{array}$ & 1.10 \\
\hline Best Estimate & & 0.25 & & 1.23 \\
\hline
\end{tabular}


Table 2.8 Contents of Palisades Nuclear Plant Capsule A-60.

\begin{tabular}{|c|c|c|c|}
\hline Material/Monitor & $\begin{array}{c}\text { Charpy } \\
\text { Specimens }\end{array}$ & $\begin{array}{c}\text { Tensile } \\
\text { Specimens }\end{array}$ & Other \\
\hline Plate & 12 & 3 (longitudinal) & \\
\hline Surveillance Weld & 12 & 3 & \\
\hline HAZ Weld & 12 & 3 & \\
\hline HSST Plate 01 & 12 & & \\
\hline $\begin{array}{l}\text { Iron attenuation } \\
\text { Monitor }\end{array}$ & & & 15 \\
\hline $\begin{array}{c}\text { Temperature Monitors } \\
\text { Total of } 12\end{array}$ & & & $\begin{array}{l}\text { 3: } 92.5 \% \mathrm{~Pb}, 5.0 \% \mathrm{Sn}, 2.5 \% \mathrm{Ag} \\
\text { 3: } 90.0 \% \mathrm{~Pb}, 5.0 \% \mathrm{Sn}, 5.0 \% \mathrm{Ag} \\
\text { 3: } 97.5 \% \mathrm{~Pb}, 2.5 \% \mathrm{Ag} \\
\text { 3: } 92.5 \% \mathrm{~Pb}, 0.75 \% \mathrm{Sn}, 1.75 \% \mathrm{Ag}\end{array}$ \\
\hline $\begin{array}{c}\text { Spectrum Monitors } \\
\text { Total of } 21\end{array}$ & & & $\begin{array}{l}\text { 3: uranium powder } \\
\text { 3: titanium } \\
\text { 3:iron } \\
\text { 3: sulfur in quartz } \\
\text { 3: cadmium shielded uranium powder } \\
\text { 3: cadmium shielded nickel } \\
\text { 3: cadmium shielded copper }\end{array}$ \\
\hline
\end{tabular}




\section{SUMMARY AND CONCLUSIONS}

The primary objective of the LWRSP RPV task is to develop robust predictions of transition temperature shifts (TTS) at high fluence $(\phi t)$ to at least $10^{20} \mathrm{n} / \mathrm{cm}^{2}(>1 \mathrm{MeV})$ pertinent to plant operation of some pressurized water reactors (PWR) for 80 full power years. The RPV task of the LWRS Program is working with various organizations to obtain archival surveillance materials from commercial nuclear power plants to allow for comparisons of the irradiation-induced microstructural features from reactor surveillance materials with those from similar materials irradiated under high flux conditions in test reactors. Small pieces of surveillance specimens from the Ringhals nuclear plants, Units 3 and 4, were received from Vattenfal, Inc. in Sweden, have been examined with atom probe tomography and exhibit relatively large irradiation-induced precipitates containing nickel, manganese, and silicon, with phosphorus evident in some of the precipitates and only a relatively few number of copper atoms. Previously tested Charpy impact surveillance specimens of forging, weld metal, and heat-affected-zones from the R. E. Ginna Nuclear Plant have been received from Westinghouse and have been tested to determine their microhardness to enable identification of the forging and weld portions of the heat-affected-zone specimens. The forging and weld specimens revealed a clear difference in microhardness reflective of the published difference in their tensile strengths. Measurements of the HAZ specimens, however, have not provided definitive results and further testing is underway to enable their identification. Folliwing clear identification, they will be sectioned to enable fabrication of samples for microstructural examination using atom probe tomography and small-angle neutron scattering. Examination of the copper and nickel contents of the surveillance and HAZ weld show very large scatter of nickel content that will require specific measurements of microstructural specimens fabricated from those welds. Negotiations have been held with personnel of the Palisades Nuclear Power Plant and Westinghouse regarding retrieval of Capsule A-60 from the reactor spent fuel pool. The current target date for retrieval of the capsule by Westinghouse is February 2013. 


\section{REFERENCES}

1. Eason, E. D., Odette, G. R., Nanstad, R. K., and T. Yamamoto, "A Physically Based Correlation of Irradiation-Induced Transition Temperature Shifts for RPV Steels," ORNL/TM-2006/530, Oak Ridge National Laboratory, February 2007.

2. Nanstad, R. K. and Odette, G. R., "Reactor Pressure Vessel Issues for the Light-Water Reactor Sustainability Program," Proceedings of Env. Deg. Conf., 2009.

3. Odette, G. R. and Nanstad, R. K., "Predictive Reactor Pressure Vessel Steel Irradiation Embrittlement Models: Issues and Opportunities," J. Metals, 61, 7, July 2009.

4. Nanstad, R. K., "Reactor Pressure Vessel Task of Light Water Reactor Sustainability Program: Assessment of High Value Surveillance Materials," ORNL/LTR-2011/172, Oak Ridge National Laboratory, June 2011.

5. Nanstad, R. K., "Reactor Pressure Vessel Task of Light Water Reactor Sustainability Program: M3LW-12OR0402012 - Letter Report on Metallurgical Examination of the High Fluence RPV Specimens From the Ringhals Nuclear Reactors," ORNL/LTR2012/113, Oak Ridge National Laboratory, March 2012.

6. Nanstad, R. K., "Reactor Pressure Vessel Task of Light Water Reactor Sustainability Program: Level 3 Milestone (M3W-12OR0402014) - Progress Report on Examinations of the Surveillance Specimens from the Ginna and Palisades Reactors," ORNL/LTR2012/335, Oak Ridge National Laboratory, August 2012.

7. G. R. Odette and G.E. Lucas, Radiation Effects and Defects in Solids, 144 (1-4) (1998), p. 189.

8. G. R. Odette, Microstructural Evolution During Irradiation, MRS Symp. Proc. 373 (Warrendale, PA: Materials Research Society, 1995), p. 137.

9. G. R. Odette, Irradiation Effects on Pressure Vessel Steels, IAEA IRRWG-LMNPP-98-3 (Vienna, Austria: International Atomic Energy Agency, 1998), p. 438.

10. G. R. Odette and B.D. Wirth, J. Nucl. Matls., 251 (1998), p. 157.

11. G. R. Odette, T. Yamamoto, and B.D. Wirth, Proceedings of the Second International Conference on Multiscale Modeling (University of California Los Angeles, 2004), p. 105.

12. M.K. Miller and K.F. Russell, "Embrittlement of RPV Steels: An Atom Probe Tomography Perspective,” J. Nucl. Matls., 37 (1-3) (2007), p. 145.

13. P. Efsing, C. Jansson, T. Mager, and G. Embring, "Analysis of the Ductile-to-Brittle Transition Temperature Shift in a Commercial Power Plant with High Nickel Containing Weld Material," J. ASTM Int., Vol. 4, No. 7, Paper ID JAI100719, 2007, Available online at www.astm.org. 
14. U.S. Nuclear Regulatory Commission, "Radiation Embrittlement of Reactor Vessel Materials," Regulatory Guide 1.99, Revision 2 (Washington, D.C.: U.S. Nuclear Regulatory Commission, 1988).

15. Electropolishing Method for APT

16. Rosier, B. A., "Analysis of Capsule $\mathbf{N}$ from the R. E. Ginna Reactor Vessel Radiation Surveillance Program," WCAP-17036-NP, Westinghouse Non-Proprietary Class E, September 2010. 


\section{INTERNAL DISTRIBUTION}

1. J. T. Busby

3. R. K. Nanstad

5. M. A. Sokolov
2. G. E. Ice

4. T. M. Rosseel

\section{EXTERNAL DISTRIBUTION}

K. McCarthy, Idaho National Laboratory, P.O. Box 1625, Idaho Falls, ID 83415-3860, (Kathryn.Mccarthy@inl.gov)

P. Finck, Idaho National Laboratory, P.O. Box 1625, Idaho Falls, ID 83415-3860, (Phillip.Finck@inl.gov)

R. Reister, GTN Bldg, 1000 Independence Ave, S.W. Washington, DC 20585, (Richard.Reister@nuclear.energy.gov) 